\title{
ANALISIS SEMIOTIKA ROLAND BARTHES PADA RITUAL OTONAN DI BALI
}

\author{
Putu Krisdiana Nara Kusuma, Iis Kurnia Nurhayati \\ Prodi S1 Ilmu Komunikasi Fakultas Komunikasi dan Bisnis Universitas Telkom
}

\begin{abstract}
ABSTRAK
Indonesia yang terdiri dari banyaknya pulau, kepulauan, serta provinsi, membuat negara ini memiliki berbagai macam budaya yang tentu saja berbeda satu dengan yang lainnya. Salah satu contohnya adalah Bali, yang terkenal dengan daerah wisatanya yang menarik serta budayanya yang sangat kental. Hingga saat ini, masyarakat di Bali masih memegang teguh kebudayaan mereka, khususnya bagi masyarakat Bali yang beragama Hindu. Ada banyak ritual keagamaan yang erat dengan budaya Bali yang saat ini masih dipegang teguh dan bahkan masih dilaksanakan oleh masyarakatnya. Salah satu contohya adalah ritual Otonan, yaitu perayaan hari kelahiran dalam adat Bali. Hal yang menarik dari Otonan ini adalah bahwa di era globalisasi seperti sekarang ini, saat masyarakat lebih mengadopsi budaya barat, ternyata masih ada masyarakat yang tetap memegang teguh budaya serta kewajiban agamanya. Penelitian ini menggunakan metode kualitatif dengan analisis semiotika dari Roland Barthes. Tujua dari penelitian ini adalah untuk menganalisis makna denotative, konotatif, serta mitos dan ideologi dalam ritual Otonan. Berdasarkan hasil penelitian, ditarik kesimpulan pemaknaan denotatif pada prosesi Mebyakaonan ritual Otonan yaitu berupa serangkaian kegiatan dalam Mebyakaonan ritual Otonan, di mana visual ditandai dengan gestur, pakaian, dan warna, verbal ditandai dengan doa-doa, dan audio ditandai dengan bunyi lonceng. Terdapat pemaknaan konotasi yang erat dengan ajaran agama Hindu seperti ajaran Tri Murti, Sad Ripu, makna air tirtha, dll, serta berbagai mitos dan ideologi seperti hierofani, ungkapan religius kolektif, religiusitas, serta agama sebagai sistem budaya.

Kata kunci: Semiotika, Roland Barthes, Ritual, Bali
\end{abstract}

\section{PHENOMENOLOGICAL STUDY OF INTERPERSONAL COMMUNICATION COMMUNITY MEMBERS IN INDIGO CHILDREN}

\begin{abstract}
Indonesia consists of many islands and provinces, making the country had a wide range of cultures which is of course different from one another. For example, Bali. Bali have been well-known by its interesting tourism destinations and also its timeless culture. Until these days, the Balinese still holding their culture, especially for the Hindu Balinese. There are so many religious ritual that close to Balinese culture are still being held by them. One of the ritual is Otonan. Otonan is a birth-day celebration in Balinese culture. The interesting thing from Otonan is that in this globalization era, when the public is adopting western culture, evidently there are still people who hold their culture and their religious responsibilities. This research uses qualitative method with semiotics analysis by Roland Barthes. The purpose of this research is to find out the denotative, connotative, and also the myth and ideology in Otonan ritual. Based upon the result of the research, the conclusion is that the denotative in Mebyakaonan of Otonan ritual is in the form of Mebyakaonan in Otonan ritual. The visual signs are the gestures, clothes, and colors, the verbal sign is the prayer or the invocations for
\end{abstract}

ISSN: 2548-3242 (cetak), eISSN: 2549-0079 Website: http://jurnal.unpad.ac.id/manajemen-komunikasi 
each steps (Mebyakaonan and Meprayascitta), and the audio sign is the bell sound. The connotative is related Hinduism theory such as Tri Murti, Sad Ripu, the meaning of tirtha, etc, and also the myths and ideologies such as hierofani, collective religious expression, religiosity, and religion as a culture system.

Keywords: Semiotics, Roland Barthes, Ritual, Bali

Korespondensi: Putu Krisdiana Nara Kusuma. Universitas Telkom. Jl. Telekomunikasi, Jl. Terusan Buah Batu No.01, Dayeuhkolot, Bandung, Jawa Barat 40257.Email: krisdiananara@ gmail.com

\section{PENDAHULUAN}

Komunikasi tidak akan pernah bisa lepas dari adanya visual dan verbal. Visual ditandai dengan gambar, verbal ditandai dengan lisan maupun tulisan. Antara visual dengan verbal ini pun memiliki hubungan yang erat. Meskipun jika dalam komunikasi hanya terdapat salah satu dari visual ataupun verbal, komunikasi tetap akan berjalan, namun dengan pemahaman yang terbatas. Akan tetapi, jika dalam komunikasi terdapat kedua hal ini (visual dan verbal), maka tingkat pemahaman akan menjadi lebih tinggi. Dalam kehidupan sehari-hari, bahasa verbal (baik lisan maupun tutlisan) selalu memegang peranan yang penting dalam sebuah interaksi serta dipandang sebagai sarana interaksi yang utama, sedangkan bahasa non-verbal dan sarana visual dianggap kurang penting, padahal banyak hasil kerja yang bernilai yang selalu dikaitkan dengan tanda verbal dan nonverbal. Bahasa verbal saja tanpa semua gerak gerak, suara, warna, dan objek material membatasi pemahaman kita terhadap kompleksnya sebuah interaksi dan makna interaksional dapat memberikan pengaruh terbatas pada suatu komunikasi (Sinar, 2012:131).

Bahasa verbal termasuk bahasa lisan dan tulis sedangkan komponen hasil keluaran bahasa verbal adalah bunyi atau suara dan tulisan atau graf. Interaksi visual merupakan bahasa non-verbal yang termasuk di dalamnya adalah gestur, bahasa tubuh seperti gerakan kepala, badan, warna, dan objek material, tatapan (gaze) seseorang, dll. Manusia melakukan kegiatan sosial seharihari dengan cara mengirim dan menerima pesan-pesan yang dapat ditransmisi melalui komunikasi tulis ataupun lisan, dan berbagai jenis telekomunikasi. (Sinar, 2012:131). Ada pula yang disebut sebagai audio, yang merupakan suara atau bunyi yang dihasilkan oleh getaran suatu benda. Segala hal yang dapat ditangkap oleh indera pendengaran merupakan audio. Dalam hal ini, audio biasanya berfungsi untuk melengkapi proses komunikasi, di mana audio mampu membantu dalam penyampaian isi pesan agar lebih berkesan. Suatu komunikasi jika terdiri 
dari visual, verbal, serta didukung oleh keberadaan audio tentunya akan lebih mudah dalam penyampaian pesan serta menciptakan sebuah suasana tersendiri.

Cara berpikir, ide bahkan harapan yang dihubungkan dengan cara berpikir merupakan simbol dalam berkomunikasi. Selain itu norma dan cara pandang di dalam masyarakat juga merupakan sebuah simbol (Novianti, 2014:162).

Semiotika, sebagaimana dijelaskan oleh Ferdinand de Saussure dalam Course in General Linguistics, adalah "ilmu yang mempelajari peran tanda sebagai bagian dari kehidupan sosial. Semiotika adalah ilmu yang mempelajari struktur, jenis, tipologi, serta relasi-relasi tanda dalam penggunaannya di dalam masyarakat (Piliang, 2012:47). Ada sejumlah bidang terapan semiotika. Dalam artian, semiotika dapat digunakan untuk banyak bidang terapan yang tidak terbatas, mulai dari pemberitaan media massa, komunikasi periklanan, tanda-tanda nonverbal, film, komik-kartun, sastra, musik, hingga budaya.

Indonesia yang terdiri dari banyaknya pulau, kepulauan, serta provinsi, membuat negara ini memiliki berbagai macam budaya yang tentu saja berbeda satu dengan yang lainnya. Salah satu contohnya adalah Bali, yang terkenal dengan daerah wisatanya yang menarik serta budayanya yang sangat kental. Hingga saat ini, masyarakat di Bali masih memegang teguh kebudayaan mereka, khususnya bagi masyarakat Bali yang beragama Hindu. Ada banyak ritual keagamaan yang erat dengan budaya Bali yang saat ini masih dipegang teguh dan bahkan masih dilaksanakan oleh masyarakatnya. Salah satu contohya adalah upacara Otonan, yaitu perayaan hari kelahiran dalam adat Bali. Otonan berasal dari kata "wetu" yang berarti lahir. Kemudian kata ini menjadi "pawetuan" yang dapat ditafsirkan sebagai kelahiran. Kata pawetuan berubah menjadi kata "paweton", dan akhirnya menjadi kata oton atau otonan yang berarti hari kelahiran (Sumber: http://catatanbiodatadiri.blogspot.co.id/2013/1 2/lunturnya-tradisi-budaya-otonan.html diakses pada tanggal 23 Agustus 2016, pukul 19.50 WIB). Otonan merupakan peringatan hari kelahiran bagi umat Hindu di Bali berdasarkan satu tahun Wuku. Jatuhnya otonan akan sama dengan Sapta Wara, Panca Wara dan Wuku yang sama. Artinya, otonan akan diperingati pada hari yang sama dan dirayakan setiap enam bulan sekali.

Otonan diperingati sebagai hari kelahiran dengan melaksanakan upakara yadnya (upacara adat yang merupakan persembahan secara ikhlas) kecil dan biasanya dipimpin oleh orang yang dituakan atau bila upakaranya lebih besar dipimpin oleh pemangku (pendeta). Umumnya, Otonan diperingati selama seseorang masih hidup, artinya meskipun seseorang itu sudah tua, tetap saja ia memperingati Otonan. Otonan merupakan 
salah satu bentuk upacara yang merupakan bagian dari Manusa Yadnya yang sesungguhnya bertujuan untuk menyucikan manusia itu secara lahir dan bathin di samping sebagai bentuk peringatan akan perubahan umur orang yang bersangkutan. Otonan dilakukan setiap 6 bulan sekali menurut perhitungan kalender Bali. Meskipun pelaksanaan otonan dalam skala yang kecil, namun selama hidupnya manusia wajib melaksanakan Otonan, tidak boleh tidak melaksanakan sama sekali. Dalam memperingati Otonan, umumnya dibuatkan berbagai macam sesajen yang memang khusus digunakan untuk upacara Otonan. Perayaannya pun beragam, mulai dari kecil, sedang, hingga besar. Hal itu dapat dilihat dari jenis sesajen yang digunakan. Ada yang kecil, sedang, maupun yang besar.

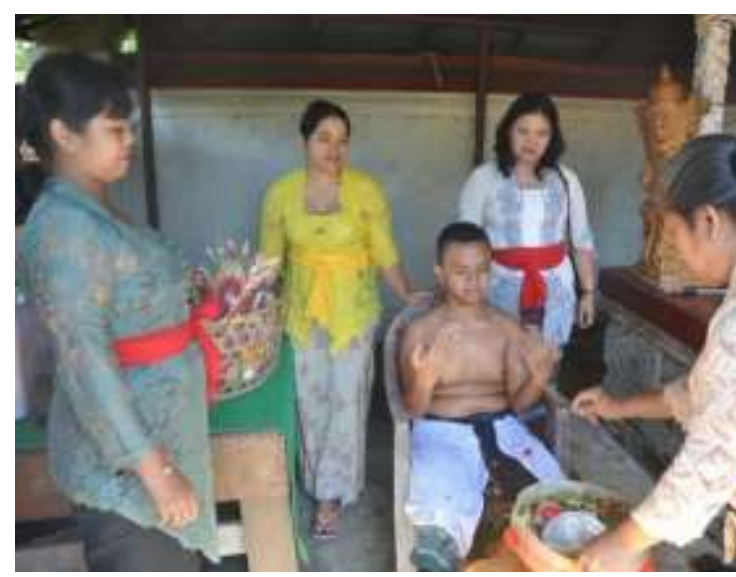

Gambar 1 Ritual Otonan di Bali

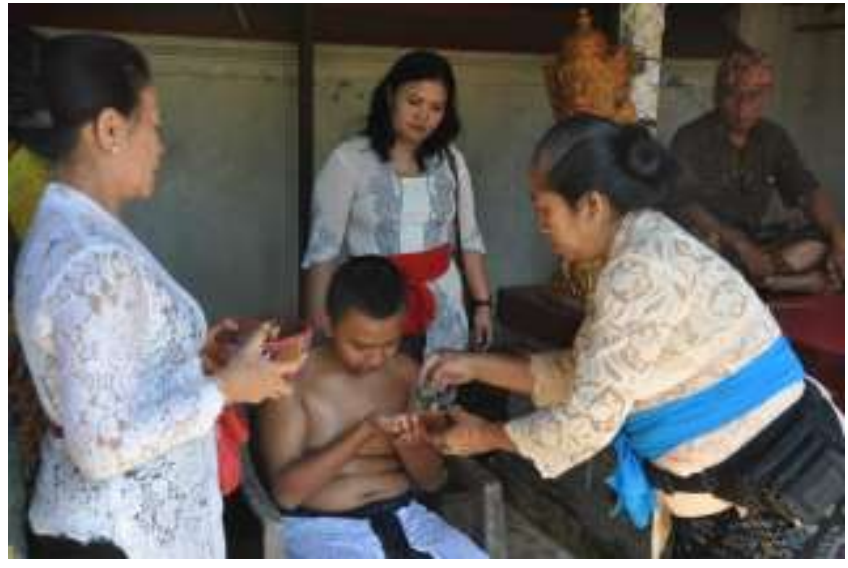

Gambar 2 Ritual Otonan di Bali

Dalam Otonan, umat Hindu senantiasa menghaturkan puja dan puji angayubagia (syukur) kepada Ida Sang Hyang Widhi Wasa atas anugerah yang telah dilimpahkan selama ini. Dengan waktu pelaksanaannya yang mengambil waktu 6 bulan sekali, idealnya umat Hindu diharapkan lebih meningkatkan sradha dan bhakti-nya serta bersyukur atas karunia yang telah diperoleh selama enam bulan hidup yang telah ia lalui. Hal yang sangat menarik sehingga peneliti mengangkat Otonan sebagai tema adalah bahwa di era modern seperti sekarang ini, di mana globalisasi membuat hampir seluruh masyarakat dunia meniru budaya barat seperti merayakan ulangtahun di setiap tahunnya, masyarakat Hindu di pulau Bali tetap memegang teguh kebudayaan mereka ini. Hingga saat ini, mereka tetap melaksanakan upacara Otonan setiap 6 bulan sekali, sesuai dengan jadwal Otonan mereka, baik itu dilaksanakan besar-besaran ataupun hanya sederhana. Berbeda dengan budaya 
modern yang memperingati ulangtahun 12 bulan sekali, Otonan yang diperingati 6 bulan sekali ini memiliki perhitungan tersendiri dalam menentukan hari Otonan. Perhitungan tersebut meliputi hari kelahiran, wuku, panca wara, dan sapta wara. Misalkan orang yang lahir pada wuku Landep, pada hari Selasa (Anggara) Umanis, maka otonan selanjutnya akan dilakukan 6 bulan berikutnya pada wuku, dan panca wara serta sapta wara yang sama.

Mengapa Otonan? Karena upacara Otonan ini mengajarkan kita untuk mampu menghargai segala hal yang ada di dunia ini. Upacara Otonan merupakan salah satu upacara Manusa Yadnya yang ditujukan untuk diri sendiri, sehingga Otonan merupakan saat yang tepat untuk kita memberikan sebuah perayaan untuk diri kita sendiri, namun tetap ingat untuk bersyukur kepada Tuhan. Selain itu, Otonan juga membantu pelaksananya untuk membersihkan dirinya setelah 6 bulan kehidupan yang telah ia lalui. Dengan melaksanakan Otonan, kita memberikan sebuah perayaan bagi hari kelahiran, namun tetap dengan memegang teguh keimanan dan budaya masyarakat Hindu di Bali.Ritual Otonan ini terdiri dari dua prosesi, yaitu Mebyakaonan dan Meprayascitta. Penelitian ini akan membedah prosesi Mebyakaonan, karena dalam prosesi ini lebih menunjukkan bagaimana manusia hidup berdampingan dengan yang sakral, serta bagaimana hubungan antara agama dengan kebudayaan. Penelitian ini diharapkan dapat menjelaskan kepada masyarakat dalam membaca makna yang terkandung dalam sebuah ritual, baik itu dari tanda visual, verbal, maupun audio, dengan metode analisis semiotika. Selain itu penelitian ini diharapkan dapat menjadi masukan bagi peneliti-peneliti lain untuk melakukan penelitian lebih lanjut mengenai ritual Otonan dengan menggunakan pendekatan-pendekatan lainnya.

Aspek-aspek dalam otonan yang menarik untuk ditelaah adalah:

\section{Warna}

Kemampuan untuk mempersepsikan warna dalam berbagai wujud merupakan dasar dari banyak aktivitas pembuatan dan penggunaan tanda di seluruh dunia. Pada level denotatif, kita menafsirkan tanda sebagai gradasi rona dalam spectrum cahaya (Danesi, 2010:97). Dari segi semiotik, istilah warna adalah penanda verbal yang mendorong orang untuk cenderung memperhatikan terutama rona-rona yang disandikan oleh penanda tersebut (Danesi, 2010:103).

\section{Pakaian}

Metode dasar dari semiotika adalah menanyakan apa, bagaimana, dan mengapa suatu hal memiliki makna yang saat ini dimilikinya, tidak terkecuali pada pakaian. Pakaian saat ini tidak hanya berperan sebagai penutup badan ataupun sebagai perindungan. 
Pakaian merupakan sistem tanda yang saling terkait dengan sistem-sistem tanda lainnya dalam masyarakat, dan melalui hal tersebut kita dapat mengirimkan tentang sikap kita, status sosial kita, kepercayaan politik kita, dsb (Danesi, 2010:255). Artinya, pakaian dapat dikatakan sebagai identitas diri dari seseorang. Karena pakaian dikenakan di tubuh, dan keran tubuh merupakan sebuah tanda diri, pakaian dapat didefinisikan sebagai tanda yang memperluas makna dasar tubuh dalam konteks budaya. Karena itu, pakaian dan tubuh yang ditutupi olehnya disusupo oleh signifikansi moral, sosial, dan estetis (Danesi, 2010:255).

\section{Makna}

Makna merupakan konsep yang abstrak. Menurut Kincain dan Schramm (dalam Sobur, 2013:244), makna terkadang berupa suatu jalinan asosiasi, pikiran yang berkaitan serta perasaan yang melengkapi konsep yang diterapkan. Ada beberapa pendapat mengenai jenis dan tipe makna. Brodbeck (dalam Sobur, 2013:262) menyajikan teori mengenai makna dengan cara yang sederhana. Makna yang pertama adalah inferensial, yaitu makna suatu kata atau lambang adalah objek, pikiran, gagasan, atau konsep yang dirujuk oleh kata tersebut. Makna yang kedua adalah arti (significance) dari suatu istilah sejauh dihubungkan dengan konsep-konsep yang lainnya. Makna yang ketiga adalah makna intensional, yaitu makna yang dimaksud oleh orang yang menggunakan lambang tersebut. Namun meskipun banyak jenis dan tipe, salah satu cara yang digunakan oleh para ahli untuk membahas mengenai ruang lingkup makna yang lebih luas dan lebih besar ini adalah dengn membedakan makn menjadi dua, yaitu makna denotatif dan makna konotatif (Sobur, 2013:262).

\section{Kebudayaan}

Banyak yang mengatakan bahwa kebudayaan merupakan seni. Padahal patut diingat bahwa kebudayaan bukan sekadar sebuah seni, kebudayaan melebihi seni itu sendiri karena kebudayaan meliputi sebuah jaringan kerja dalam kehidupan manusia (Liliweri, 2002:7). Iris Varner dan Linda Beamer (dalam Liliweri, 2002:9) menguraikan beberapa definisi kebudayaan. Salah satunya adalah kebudayaan merupakan pandangan hidup dari sekelompok orang dalam bentuk perilaku, kepercayaan, nilai, dan simbol-simbol yang mereka terima tanpa sadar/tanpa dipikirkan, yang semuanya diwariskan melalui proses komunikasi dan peniruan dari satu generasi ke generasi berikutnya. Arti kebudayaan dalam bahasa sehari-hari adalah segala sesuatu yang indah, misalnya candi, tarian, seni rupa, seni suara, kesasteraan, dan filsafat. Sedangkan menurut antropologi, kebudayaan adalah seluruh sistem gagasan dan rasa, tindakan, serta karya yang dihasilkan manusia dalam 
kehidupan bermasyarakat, yang dijadikan miliknya dengan belajar (Koentjaraningrat, 2011:72). Berdasarkan pengertian di atas, telah jelas bahwa kebudayaan melibatkan sekelompok orang, bukan hanya sekedar individu. Kebudayaan yang dimiliki sekelompok manusia sangat beragam. Hal ini dipengaruhi atas nilai dan norma yang dianut pada kelompok tersebut. Kebudayaan sangatlah mempengaruhi perilaku manusia karena setiap orang akan menampilkan kebudayaannya apabila bertindak.

\section{Ritual}

Ritual bisa dikatakan sebagai tindakan simbolis agama, atau ritual itu merupakan “agama dalam tindakan”. Susanne Langer (dalam Ghazali, 2011:52) menunjukkan bahwa ritual merupakan ungkapan yang bersifat logis daripada hanya bersifat psikologis. Ritual memperlihatkan tatanan atas simbol-simbol yang diobjekkan. Simbolsimbol ini mengungkapkan perilaku dan perasaan serta membentuk disposisi pribadi dari para pemuja yang mengikuti modelnya masing-masing. Dalam setiap ritual yang dilaksanakan, terdiri dari banyak simbolsimbol yang memiliki maknanya tersendiri. Menurut Ghazali (2011:63), fungsi dari simbol-simbol yang digunakan dalam ritual adalah sebagai alat komunikasi dan menyuarakan pesan-pesan ajaran agama dan kebudayaan yang dimilikinya, khususnya yang berkaitan dengan etos dan pandangan hidup, sesuai dengan tujuan yang ingin dicapai oleh adanya upacara tersebut.

\section{Semiotika}

Roland Barthes dikenal sebagai salah seorang pemikir strukturalis yang getol mempraktikkan model linguistik dan semiologi Saussure. Dirinya berpendapat bahasa adalah sebuah sistem tanda yang mencerminkan asumsi-asumsi dari suatu masyarakat tertentu dalam waktu tertentu (dalam Sobur, 2013:63). Barthes mengutamakan tiga hal yang menjadi inti dalam analisisnya, yaitu makna Denotatif, Konotatif, dan Mitos. Sistem pemaknaan tingkat pertama disebut dengan Denotatif, dan sistem pemaknaan tingkat kedua disebut dengan Konotatif. Denotatif mengungkap makna yang terpampang jelas secara kasat mata, artinya makna denotatif merupakan makna yang sebenarnya. Sedangkan Konotatif atau pemaknaan tigkat kedua mengungkap makna yang terkandung dalam tanda-tanda. Berbeda dengan mitos, yang ada dan berkembang dalam benak masyarakat karena adanya pengaruh sosial atau budaya masyarakat itu sendiri akan sesuatu, dengan cara memperhatikan dan memaknai korelasi antara apa yang terlihat secara nyata (denotatif) dengan tanda apa yang tersirat dari hal tersebut (konotasi). 


\begin{tabular}{|ll|l|}
\hline $\begin{array}{l}\text { 1. } \\
\text { Signi } \\
\text { fier } \\
\text { (pena } \\
\text { nda) }\end{array}$ & $\begin{array}{c}\text { 2. Signified } \\
\text { (petanda }\end{array}$ \\
\hline 3. & $\begin{array}{l}\text { Denotative sign } \\
\text { (tanda denotatif) }\end{array}$ \\
\hline 4. & $\begin{array}{l}\text { Connotative } \\
\text { signifier (penanda } \\
\text { konotatif) }\end{array}$ & $\begin{array}{l}\text { 5. } \\
\text { Connotative } \\
\text { signified } \\
\text { (petanda } \\
\text { konotatif) }\end{array}$ \\
\hline \multicolumn{2}{|l|}{ 6. Connotative sign (tanda konotatif) } \\
\hline \multicolumn{2}{|c|}{ Gambar 3 Peta Tanda Roland Barthes } \\
\hline
\end{tabular}

\section{METODE PENELITIAN}

Paradigma penelitian adalah perspektif penelitian yang digunakan oleh peneliti tentang bagaimana peneliti melihat realita, bagaimana mempelajari fenomena, cara-cara yang digunakan dalam penelitian, dan caracara yang digunakan untuk menginterpretasikan temuan (Pujileksono, 2015:26). Paradigma konstruktivis melihat suatu realita dibentuk oleh berbagai macam latar belakang sebagai bentuk konstruksi realita tersebut. Realita yang dijadikan sebagai objek penelitin merupakan suatu tindakan sosial oleh aktor sosial. Paradigm konstruktivis bertujuan untuk memahami apa yang menjadi konstruksi suatu realita. Oleh karena itu peneliti harus dapat mengetahui faktor apa saja yang mendorong suatu realitas dapat terjadi dan dapat menjelaskan bagaimana faktor-faktor tersebut merekonstruksi realita tersebut (Pujileksono, 2015:28-29). Peneliti memilih menggunakan paradigma konstruktivisme karena dalam penelitian ini peneliti ingin mendapatkan pemahaman mengenai fakta-fakta yang dilihat pada suatu peristiwa. Peneliti ingin mengetahui bagaimana bentuk verbal, visual, dan audio yang terdapat dalam prosesi Mebyakaonan dalam ritual Otonan di Bali, yang kemudian antara verbal, visual dan audio tersebut akan dihubungkan dan ditarik sebuah makna.

Pendekatan yang digunakan pada penelitian ini adalah pendekatan kualitatif. Peneliti menggunakan penelitian kualitatif karena berkaitan dengan pembahasan yang diteliti yaitu mengenai analisis semiotika Roland Barthes pada ritual Otonan umat Hindu di Bali. Metode penelitian kualitataif adalah metode penelitian yang berlandaskan pada filsafat post-positivisme, digunakan untuk meneliti pada kondisi objek yang alamiah, di mana peneliti adalah instrumen kunci, teknik pengumpulan data dilakukan secara triangulasi, analisis data bersifat induktif/kualitatif, dan hasil penelitian kualitatif leih menekankan makna daripada generalisasi (Sugiyono, 2012:9). Pendekatan kualtatif digunakan untuk menemukan atau mengembangkan teori yang sudah ada. Pendekatan kualitatif berusaha menjelaskan realitas dengan menggunakan penjelasan deskriptif dalam bentuk kalimat (Pujileksono, 2015:35). Sementara menurut Kriyantono (2006:56), penelitian kualitatif bertujuan untuk menjelaskan fenomena dengan sedalam-dalamnya melalui pengumpulan data sedalam-dalamnya. 
Penelitian ini bersifat deskriptif karena hanya mendeskripsikan makna denotatif dan konotatif dari setiap tanda yang ada, kemudian menjelaskan mitos dan ideologi yang ada di dalamnya.

Setelah menentukan metode penelitian, peneliti menggunakan teori semiotika Roland Barthes. Dalam analisis semiotika Roland Barthes ini, penulis menganalisis tiga tanda yaitu visual, verbal, serta audio, yang kemudian nantinya akan dihubungkan sehingga dapat menarik makna denotatif dan konotatifnya yang kemudian akan menghasilkan mitos dan ideologi. Peneliti memilih metode semiotika Roland Barthes karena metode ini dapat membantu peneliti dalam penelitian yang bersifat cultural studies ini dan dapat membantu peneliti dalam menganalisa tanda visual, verbal, serta audio yang terdapat dalam prosesi Mebyakaonan ritual Otonan di Bali yang kemudian akan ditarik makna denotatif serta makna konotatifnya, yang nantinya akan menunjukkan mitos serta ideologi yang ingin disampaikan dalam ritual Otonan di Bali. Barthes berpendapat bahasa merupakan sebuah sistem tanda yang mencerminkan asumsi-asumsi dari suatu masyarakat tertentu, serta dalam waktu tertentu (dalam Sobur, 2013:63). Sistem pemaknaan tingkat pertama disebut dengan Denotatif, dan sistem pemaknaan tingkat kedua disebut dengan Konotatif. Dalam penelitian ritual Otonan umat Hindu di Bali dalam pandangan semiotika Roland Barthes, bertujuan untuk memberikan pemahaman dan gambaran global mengenai makna-makna (denotatif dan konotatif) yang terkandung dalam ritual Otonan di Bali melalui bentuk-bentuk visual, verbal, serta audio yang ada pada ritual tersebut, yang pada akhirnya akan menunjukkan mitos dan ideologi yang ingin disampaikan dalam ritual Otonan tersebut. 


\section{Denotatif}

\section{HASIL DAN PEMBAHASAN}

Tabel 1 Tanda dan Potongan Scene pada Ritual Otonan

\begin{tabular}{|c|c|c|c|}
\hline \multicolumn{3}{|c|}{ Tanda } & \multirow{2}{*}{ Potongan Scene } \\
\hline Visual & Verbal & Audio & \\
\hline $\begin{array}{c}\text { Prosesi } \\
\text { Mebyakaonan: } \\
\text { - } \quad \text { Gestur } \\
\text { - } \quad \text { Warna } \\
\text { - } \quad \text { Pakaian }\end{array}$ & $\begin{array}{l}\text { Pukulun Sang Kala } \\
\text { Purwa, Sang Kala Sakti, } \\
\text { Sang Kala Prajamuka, } \\
\text { Sang Kala Petra, Sang } \\
\text { Kala Ngulaleng, Sang } \\
\text { Kala Suksma, aja sira } \\
\text { pati panjinga, aja sira } \\
\text { pati paprotongi, iti tadah } \\
\text { saji nira, penek lawan } \\
\text { bawang jahe, mwang } \\
\text { terasi bang, iwak antiga, } \\
\text { jinah satak lima likur, } \\
\text { lawe satukel, manawi } \\
\text { kirang tadahan sira, } \\
\text { aywa sira usil silih gawe, } \\
\text { tukunen sira ring pasar } \\
\text { agung, iki jinah satak } \\
\text { lima likur, lawe satukel, } \\
\text { wehana sanak rabin sira, } \\
\text { mwang putu nira, ndah } \\
\text { sira lungha amarah desa, } \\
\text { aja maring kene, den } \\
\text { padha siddhir astu. } \\
\text { Om Kalabhyo bhokte } \\
\text { namah swaha } \\
\text { Artinya: } \\
\text { Yang kami sucikan Sang } \\
\text { Kala Purwa, } \\
\text { Sang Kala Sakti, } \\
\text { Sang Kala Brajamuka, } \\
\text { Sang Kala Petra, } \\
\text { Sang Kala Ngulaleng, } \\
\text { Sang Kala Suksma, } \\
\text { Jangan beliau } \\
\text { menghalangi segala yang } \\
\text { hamba perlukan, jangan } \\
\text { beliau menghalangi } \\
\text { segala yang hamba } \\
\text { keluarkan, ini simbol } \\
\text { bakti hamba berupa nasi } \\
\text { tumpeng berisi bawang, } \\
\text { jahe, terasi, daging tiga }\end{array}$ & $\begin{array}{c}\text { Suara } \\
\text { lonceng }\end{array}$ & \\
\hline
\end{tabular}




\begin{tabular}{|l|l|l|}
\hline $\begin{array}{l}\text { macam, uang 25 kepeng, } \\
\text { benang sepotong, } \\
\text { seadainya kurang bakti } \\
\text { hamba, jangan beliau } \\
\text { salah sangka, dan } \\
\text { mengganggu hamba, } \\
\text { silahkan beliau mencari } \\
\text { di alam makro, ini } \\
\text { pelengkap bakti hamba, } \\
\text { berupa uang 225 kepeng, } \\
\text { ditambah selembar kain, } \\
\text { mohon disampaikan } \\
\text { kepada pengikut beliau, } \\
\text { silahkan menyebar } \\
\text { menuju tempat masing- } \\
\text { masing, semoga semua } \\
\text { selamat. }\end{array}$ & \\
Tuhan sebagai pengatur & & \\
perjalanan yang hamba & & \\
mulyakan. & \\
\hline
\end{tabular}

\section{Ritual Otonan}

Secara sederhana, makna denotatif merupakan makna yang sebenarnya dari sebuah kata. Makna denotatif adalah makna yang biasanya ada pada kamus.

1. Makna denotatif dalam doa Mebyakaonan

Doa yang diucapkan oleh pemimpin ritual pada saat prosesi Mebyakonan menggunakan bahasa Sanskerta. Makna denotasi dapat ditafsirkan sebagai makna harfiah atau makna yang sesungguhnya.
Artinya, pemaknaan tingkat pertama atau makna denotasi dari doa yang diucapkan pada prosesi Mebyakaonan merupakan pemaknaan dari bahasa Sanskerta ke dalam bahasa Indonesia. Berikut adalah makna denotasi dari doa Mebyakaonan:

Yang kami sucikan Sang Kala Purwa, Sang Kala Sakti,

Sang Kala Brajamuka,

Sang Kala Petra,

Sang Kala Ngulaleng,

Sang Kala Suksma, 
Jangan beliau menghalangi segala yang hamba perlukan, jangan beliau menghalangi segala yang hamba keluarkan, ini simbol bakti hamba berupa nasi tumpeng berisi bawang, jahe, terasi, daging tiga macam, uang 25 kepeng, benang sepotong, seadainya kurang bakti hamba, jangan beliau salah sangka, dan mengganggu hamba, silahkan beliau mencari di alam makro, ini pelengkap bakti hamba, berupa uang 225 kepeng, ditambah selembar kain, mohon disampaikan kepada pengikut beliau, silahkan menyebar menuju tempat masing-masing, semoga semua selamat.

Tuhan sebagai pengatur perjalanan yang hamba muliakan.

2. Makna denotatif dalam scene pertama prosesi Mebyakaonan

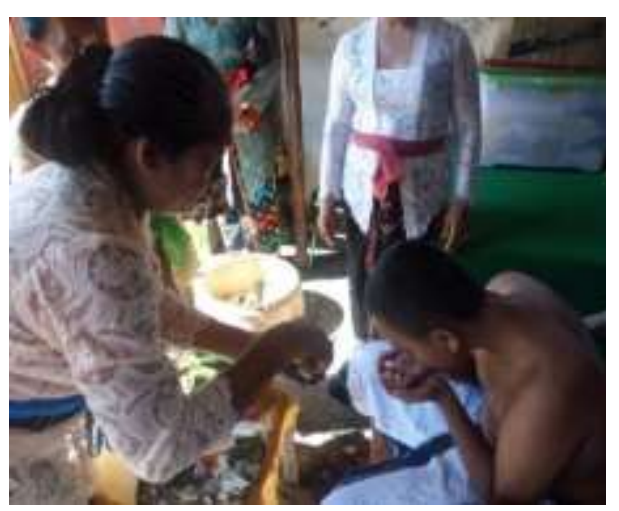

Gambar 3 scene pertama prosesi Mebyakaonan

Scene pertama pada prosesi Mebyakaonan ini dilakukan dengan cara memberikan air suci kepada peserta ritual Otonan. Masyarakat Hindu di Bali biasa menyebutnya dengan nama metirtha yang artinya menggunakan air suci. Metirtha dilakukan dengan cara mengetiskan pada kepala peserta Otonan sebanyak tiga kali, lalu memberikan air suci tersebut ke tangan peserta Otonan yang kemudian air tersebut harus diminum oleh peserta Otonan. Pemberian air suci pada tangan ini dilakukan sebanyak tiga kali, kemudian pada pemberian yang keempat, air suci dibasukan ke wajah dan kepala peserta Otonan. Pada keseluruhan prosesi dalam ritual Otonan, peserta Otonan tidak menggunakan atasan, melainkan hanya menggunakan kamen dan saput. Kamen adalah pakaian adat Bali yang berupa bawahan yang digunakan oleh seluruh masyarakat Bali sejak jaman dahulu. Tidak ada aturan warna dalam penggunaan kamen, namun saput yang digunakan adalah saput yang berwarna putih.

3. Makna denotatif dalam scene kedua prosesi Mebyakaonan

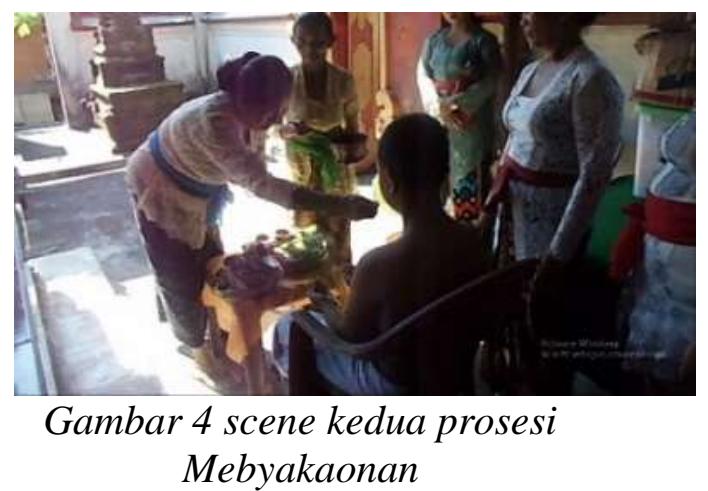

Scene kedua dalam prosesi Mebyakaonan ini dilakukan dengan cara memberikan beras pada tubuh peserta ritual Otonan. Pemberian beras ini dilakukan sebanyak 3 (tiga) kali. Selama ritual Otonan berlangsung, Srati Mangku (pembantu pemimpin ritual) menggunakan pakaian adat ke Pura, yaitu kebaya, kamen, dan selendang. 
4. Makna denotatif dalam scene ketiga prosesi Mebyakaonan



Gambar 5 scene ketiga prosesi Mebyakaonan

Scene ketiga dalam prosesi Mebyakaonan dilakukan dengan cara metirtha. Tirtha diberikan kepada peserta Otonan sebanyak tiga kali pada kepala, tiga kali pada tangan kanan peserta Otonan yang harus dimasukkan ke mulut dan dikeluarkan lagi, tiga kali pada tangan kanan peserta Otonan yang kemudian harus diminum, satu kali pada tangan kanan peserta Otonan yang kemudian diusapkan ke wajah dan kepalanya, serta tiga kali diketiskan pada kepala peerta Otonan sebagai penutup.

5. Makna denotatif dalam scene keempal prosesi Mebyakaonan

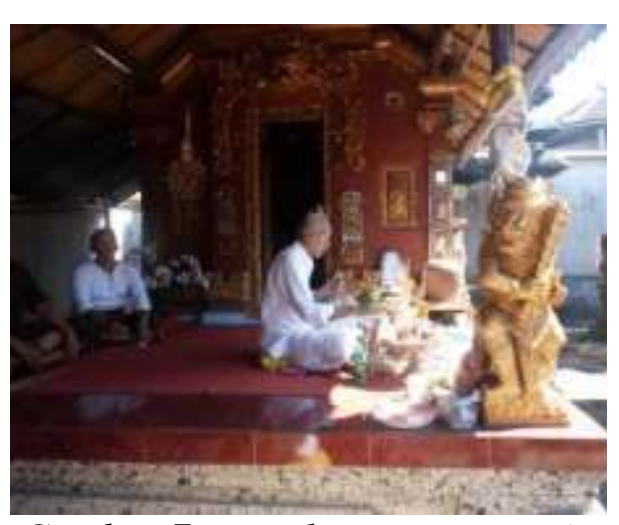

Gambar 7 scene keempat prosesi Mebyakaonan
Scene ini menunjukkan Ida Pedanda sebagai pemimpin dari ritual Otonan. Dalam ritual Otonan ini, pemimpin ritual lah yang mengucapkan doa-doa dalam setiap prosesi. Pemimpin ritual mengucapkan doa sambil membunyikan lonceng serta mengetiskan tirtha pada sekelilingnya. Pemimpin ritual mengenakan pakaian adat serba putih. Dalam ritual Otonan ini, tidak ada ketentuan penggunaan pakaian khusus Ida Pedanda, asalkan pakaian yang digunakan adalah pakaian adat yang bersih dan rapi, dan serba putih.

\section{Makna denotatif dalam audio}

Lonceng digerakkan oleh Ida Pedanda hingga menimbulkan bunyi. Lonceng ini akan terdengar selama Ida Pedanda selaku pemimpin ritual mengucapkan doa-doa dari masing-masing prosesi.

\section{Konotatif}

Makna konotatif dalam doa Mebyakaonan

Sang Kala Purwa, Sang Kala Sakti, Sang Kala Brajamuka, Sang Kala Petra, Sang Kala Ngulaleng, dan Sang Kala Suksma adalah nama-nama dari para makhluk astral yang biasa berfungsi sebagai penunggu dari suatu tempat. Dalam doa yang diucapkan untuk prosesi Mebyakaonan ini menunjukkan bahwa Ida Pedanda meminta kepada para bhuta kala (makhluk astral) yang ada di sekitarnya untuk tidak mengganggu prosesi 
ritual otonan. Ada pula benda-benda yang disebutkan dalam doa tersebut merupakan simbolis sesajen yng disediakan untuk mereka, agar para bhuta kala tersebut tidak mengganggu jalannya ritual Otonan dan bisa membantu keseluruhan prosesi ritual Otonan tersebut.

2. Makna konotatif dalam scene pertama prosesi Mebyakaonan

Dalam ajaran agama Hindu, dikenal yang namanya tiga unsur kekuatan Ida Sang Hyang Widhi Wasa, di mana segala yang ada dalam alam semesta ini akan melalui proses tiga unsur tersebut, yaitu Utpeti, Stiti, dan Pralina. Utpeti artinya penciptaan, Stiti artinya pemeliharaan, dan Pralina artinya peleburan. Ini selaras dengan 3 manifestasi dari Sang Hyang Widhi yaitu Tri Murti, yang terdiri dari Brahma (pencipta), Wisnu (pemelihara), dan Siwa (pelebur). Proses metirtha yang dilakukan sebanyak tiga kali melambangkan bahwa setiap elemen di alam semesta ini (termasuk peserta Otonan) akan melalui proses Utpeti, Stiti, dan Pralina dalam hidupnya. Maka dari itu, dengan mendapatkan tirtha (air suci), diharapan bahwa dalam menjalani proses-proses tersebut, manusia tetap dalam keadaan dianugerahi secara batin. Dengan mengusapkan tirtha keempat pada kepala dan wajah, melambangkan bahwa peserta Otonan telah dibersihkan dan dianugerahi secara lahir. Dalam pelaksanaan ritual
Otonan, peserta Otonan tidak menggunakan atasan tanpa ada aturan tertentu. Satusatunya alasan adalah bahwa peserta Otonan tidak menggunakan atasan karena ritual ini akan membuat tubuh peserta Otonan menjadi basah. Menurut J.C.Cooper (2013:41), warna putih memiliki makna kesucian, keluguan, kesederhanaan, dan identik dengan spiritual. Warna putih menurut agama Hindu (J.C.Cooper, 2013:42) memiliki makna pure consciousness, yang artinya kesadaran akan adanya sesuatu yang suci di dalam diri, sesuatu yang spiritual, dan menyadari adanya hubungan antara diri dengan alam sekitar.

3. Makna konotatif dalam scene kedua prosesi Mebyakaonan

Ada sebuah peribahasa yang mengatakan "Menanak semua berasnya" (sumber: https://rebanas.com/kamus-

peribahasa/proverbs?kata=beras diakses pada tanggal 20 Desember 2016, pukul 16.27 $W I B)$, dengan pengertian seseorang yang memperlihatkan semua kelebihannya. Kegiatan memberikan beras pada tubuh peserta ritual Otonan ini dengan harapan agar anak tersebut di kemudian hari mempergunakan kelebihan-kelebihan yang dia miliki, sehingga dirinya bisa berguna bagi orang-orang di sekitarnya. Pemberian beras pada tubuh peserta Otonan yang dilakukan sebanyak 3 (tiga) kali, selaras dengan ajaran agama Hindu yaitu tiga unsur kekuatan Ida Sang Hyang Widhi Wasa, di 
mana segala yang ada dalam alam semesta ini akan melalui proses tiga unsur tersebut, yaitu Utpeti, Stiti, dan Pralina. Utpeti artinya penciptaan, Stiti artinya pemeliharaan, dan Pralina artinya peleburan. Dalam hal ini, pemberian beras pada tubuh peserta Otonan yang dilakukan sebanyak tiga kali diharapkan bahwa hal-hal buruk yang berada dalam diri peserta Otonan dapat diserap oleh beras tersebut dan dikeluarkan dari dalam diri peserta Otonan. Penggunaan pakaian adat ke Pura oleh para Srati Mangku menunjukkan bahwa meskipun dalam pelaksanaan ritual dengan tujuan keagamaan, masyarakat Hindu di Bali tetap tidak meninggalkan budayanya. Penggunaan kebaya dan kamen yang menutupi badan memiliki makna konotasi untuk menutupi ego dan kesombongan manusia. Penggunaan selendang memiliki makna bahwa manusia harus mampu mengikat dirinya agar tidak melenceng dari ajaran dharma.

4. Makna konotatif dalam scene ketiga prosesi Mebyakaonan

Pemberian tirtha sebanyak tiga kali memiliki makna yang selaras dengan ajaran agama Hindu yaitu tiga unsur kekuatan Ida Sang Hyang Widhi Wasa, di mana segala yang ada dalam alam semesta ini akan melalui proses tiga unsur tersebut, yaitu Utpeti, Stiti, dan Pralina. Utpeti artinya penciptaan, Stiti artinya pemeliharaan, dan Pralina artinya peleburan. Pemberian tirtha pada peserta Otonan ini memiliki makna pembesihan secara lahir dan bathin pada diri peserta Otonan, sama seperti metirtha pada scene pertama prosesi Mebyakaonan. Yang berbeda adalah terdapat prosesi yang menujukkan peserta Otonan memasukkan tirtha ke dalam mulutnya lalu dikeluarkan lagi. Hal ini memiliki makna membuang segala macam kotoran yang ada dalam diri peserta Otonan, seperti penyakit, limbah, dll. Setelah itu, peserta Otonan diberikan tirtha lagi untuk diminum, yang berarti membersihkan dirinya dan mengisi ulang kekuatan untuk daya cipta, pemeliharaan, serta penyeleksian dalam dirinya.

5. Makna konotatif dalam scene keempat prosesi Mebyakaonan

Ida pedanda adalah tokoh yang dituakan dalam masyarakat Hindu di Bali, yang memiliki kemampuan dan pengetahuan agama yang melebihi masyarakat biasa. Dalam budaya lain, Ida Pedanda biasa disebut dengan nama Pendeta. Ida Pedanda membunyikan lonceng selama mengucapkan doa memiliki makna konotasi bahwa bunyi dari lonceng tersebut akan mengiringi doadoa yang ia panjatkan. Lonceng memang sering digunakan dalam berbagai ritual keagamaan untuk berbagai umat, seperti umat Buddha dan Kristiani. Menurut J.C.Cooper (2013:41), warna putih memiliki makna kesucian, keluguan, kesederhanaan, dan identik dengan spiritual. Warna putih 
menurut agama Hindu (J.C.Cooper, 2013:42) memiliki makna pure consciousness, yang artinya kesadaran akan adanya sesuatu yang suci di dalam diri, sesuatu yang spiritual, dan menyadari adanya hubungan antara diri dengan alam sekitar. Penggunaan pakaian adat berwarna putih oleh Ida Pedanda menandakan bahwa dirinya adalah orang yang disucikan. Ida Pedanda mengetiskan tirtha pada sekelilingnya memiliki bertujuan untuk menyucikan tempat tersebut, agar ritual Otonan berjalan dengan lancar tanpa ada gangguan dan hambatan.

\section{Makna konotatif dalam audio}

Ida Pedanda membunyikan lonceng selama mengucapkan doa memiliki makna konotasi bahwa bunyi dari lonceng tersebut akan mengiringi doa-doa yang ia panjatkan. Lonceng memang sering digunakan dalam berbagai ritual keagamaan untuk berbagai umat, seperti umat Buddha dan Kristiani. Dalam ajaran agama Hindu, lonceng ini biasa disebut sebagai Genta atau Bajra. Suara lonceng yang terdengar pada saat mengucapkan doa atau memuja dapat menghilangkan suara-suara yang mengganggu pikiran dan dapat membantu pikiran untuk berkonsentrasi dalam mencapai pemujaan.

\section{Mitos dan Ideologi}

Berdasarkan analisis makna-makna yang telah dijabarkan, terdapat suatu konsep yang disebut dengan hierofani. Hierofani dapat diartikan sebagai suatu perwujudan atau penampakan diri dari yang sakral. Dalam sejarah agama-agama, mulai dari agama suku bangsa yang berkebudayaan sederhana sampai kepada agama bangsa yang sudah berkebudayaan maju, terdapat banyak hierofani sebagai bentuk dari manifestasi yang sakral (Ghazali, 2011:48). Bhuta kala adalah hierofani. Ida Pedanda sebagai pemimpin ritual Otonan adalah hierofani. Tri Murti adalah hierofani. Sapi sebagai kendaraan dewa Siwa adalah hierofani. Seluruh mitos yang ada pada ritual Otonan adalah hierofani. Serangkaian tanda visual, verbal, dan audio dalam ritual Otonan adalah hierofani. Ritual Otonan adalah hierofani. Selain itu, ritual Otonan juga merupakan ungkapan religius kolektif. Ekspresi iman yang dilakukan bersama-sama tidak dapat dipisahkan dari konteks kebudayaan bangsa tertentu (Hendropuspito, 1993:112). Hal ini selaras dengan penggunaan pakaian adat ke Pura oleh para Srati Mangku menunjukkan bahwa meskipun dalam pelaksanaan ritual dengan tujuan keagamaan, masyarakat Hindu di Bali tetap tidak meninggalkan budayanya. Dalam ritual keagamaan Hindu di daerah lain, bisa saja masyarakatnya menggunakan pakaian adat ke Pura dengan ciri khas mereka. Namun pada ritual Otonan di Bali ini, masyarakat menggunakan pakaian adat ke Pura dengan ciri khas adat Bali.

Ideologi tidak berbicara mengenai kebenaran, tidak berbicara mengenai 
kenyataan empirik, akan tetapi ideologi berbicara mengenai kemanfaatan, kepentingan, kemauan, dan pamrih (Sobur, 2013:212). Istilah ideologi dalam penggunaan David Kaplan (Kaplan, 2012:154) meliputi nilai, norma, falsafah, dan kepercayaan religius, sentimen, kaidah etis, pengetahuan atau wawasan tentang dunia, etos, dan semacamnya. Tanda visual, verbal, serta audio menghasilkan makna denotatif, konotatif, serta mitos, terdapat ideologi yang terkandung dalam ritual Otonan ini, yaitu religiusitas. Religiusitas berasal dari kata 'religi', yang lebih popular ketika membahas mengenai tradisi-tradisi dan keyakinan dalam kebudayaan manusia. Sartono Kartodirdjo (dalam Ghazali, 2011:6) menyebutkan lima unsur ke dalam dimensidimensi religiusitas yaitu dimensi pengalaman, dimensi ideologis, dimensi ritual, dimensi intelektual ideal, dan dimensi 'konsekuential'.

Ritual Otonan merupakan salah satu bentuk ritual keagamaan Hindu, khususnya untuk memenuhi Manusa Yadnya. Seluruh tanda yang ada yang tanda visual, verbal, dan audio memaknai fungsi-fungsi religius. Misalnya pada tanda visual yaitu kegiatan metirtha. Kegiatan metirtha ini bertujuan untuk memohon kepada Tuhan untuk membersihkan diri secra lahir dan batin, dengan menggunakan air tirtha sebagai medianya. Pada tanda audio yaitu bunyi lonceng yang terdengar selama Ida Pedanda mengucapkan doa, dengan maksud untuk menjernihkan pikiran, membantu berkonsentrasi, dan mengiringi doa-doa yang diucapkan. Ideologi lain adalah bahwa agama sebagai sistem budaya. Dalam kehidupan sehari-hari, agama memberikan kontribusi yang besar terhadap nilai-nilai budaya yang berlaku pada masyarakat setempat. Dalam hal ini, agama berperan sebagai sumber nilai dalam tindakantindakan sosial maupun budaya. Khususnya di Bali, di mana mayoritas masyarakatnya beragama Hindu. Contohnya pada ritual Otonan adalah penggunaan saput oleh peserta (laki-laki) selama ritual Otonan. Umat Hindu selain Hindu Bali belum tentu menggunakan pakaian adat yang sama persis dalam pelaksanaan ritual keagamaannya, contohnya adalah penggunaan saput yang digunakan di tubuh bagian bawah laki-laki, yang digunakan setelah kamen. Umat Hindu yang bukan berasal dari Bali belum tentu menggunakan saput dalam ritual keagamaannya, karena mereka memiliki sarananya sendiri. Contohnya adalah umat Hindu di Jawa (bukan asli Bali), di mana kaum laki-laki biasanya hanya menggunakan kamen ataupun sarung. Hal ini menunjukkan bahwa agama tidak akan bisa terlepas dari kebudayaan setempat.

Bali adalah nama salah satu provinsi di Indonesia yang sangat terkenal dengan kekentalan budayanya yang masih dijaga dan dilestarikan hingga saat ini. dengan 
masyarakat yang mayoritas beragama Hindu, Bali memiliki keunikan tersendiri jika dibandingkan dengan provinsi-provinsi lain di Indonesia. Selain terkenal dengan destinasi pariwisatanya serta pertunjukan budayanya, Bali juga terkenal dengan serangkaian ritual adat keagamaan (agama Hindu) yang sangat erat kaitannya dengan kebudayaan Bali. Dalam ajaran agama Hindu, dikenal dengan yang namanya Panca Yadnya yang berarti lima korban suci yang tulus dan ikhlas, yang terdiri dari Dewa Yadnya, Pitra Yadnya, Rsi Yadnya, Manusa Yadnya, serta Bhuta Yadnya. Dewa Yadnya artinya korban suci tulus ikhlas kepada Ida Sang Hyang Widhi Wasa beserta seluruh manifestasinya, Pitra Yadnya ditujukan untuk para leluhur dan orangtua, Rsi Yadnya ditujukan kepada para guru, Manusa Yadnya ditujukan untuk sesama manusia, serta Bhuta Yadnya ditujukan kepada para bhuta kala, yaitu makhluk-makhluk astral yang ada di sekitar kita.

Otonan merupakan salah satu bentuk dari Manusa Yadnya, di mana Otonan ini dilaksanakan untuk manusia. Otonan berasal dari kata "wetu" yang berarti lahir. Kemudian kata ini menjadi "pawetuan" yang dapat ditafsirkan sebagai kelahiran. Kata pawetuan berubah menjadi kata "paweton", dan akhirnya menjadi kata oton atau otonan yang berarti hari kelahiran (Sumber: http://catatanbiodatadiri.blogspot.co.id/2013/1 2/lunturnya-tradisi-budaya-otonan.html diakses pada tanggal 23 Agustus 2016, pukul 19.50 WIB). Otonan merupakan perayaan hari kelahiran yang dilaksanakan berdasarkan ajaran Hindu yang kental dengan kebudayaan Bali. Berbeda dengan hari ulangtahun yang kita kenal sekarang ini, di mana perayaan tersebut dilaksanakan setahun sekali, Otonan ini dilaksanakan enam bulan sekali. Pelaksanaan Otonan ini menghitung hari lahir manusia berdasarkan Wuku. Tujuan utama dari pelaksanaan otonan ini adalah untuk mensyukuri anugerah Ida Sang Hyang Widhi Wasa, serta untuk membersihkan diri manusia dari hal-hal negatif baik yang berasal dari luar maupun dari dalam diri manusia. Ritual Otonan dipimpin oleh seorang tokoh agama yang dimuliakan yang biasa disebut dengan Ida Pedanda. Dalam ritual Otonan, setidaknya ada tiga tanda yang dapat ditemui, yaitu tanda visual, verbal, serta audio. Penelitian ini fokus pada ketiga tanda tersebut, di mana tanda visual difokuskan pada gestur, pakaian, dan warna, tanda verbal difokuskan pada doa-doa yang diucapkan, serta tanda audio difokuskan pada bunyi lonceng (genta/bajra) yang digerakkan oleh Ida Pedanda.

Terdapat setidaknya lima kalisifikasi pesan nonverbal (Rakhmat, 2007:289-293). Salah satunyaadalah pesan gestural. Pesan gestural adalah pesan yang menggerakkan sebagian tubuh untuk mengkomunikasikan pesannya, contohnya adalah menggerakkan tangan. Dalam hal ini, Otonan memiliki 
banyak pesan gestural terkait dengan menunjukkan bagaimana manusia hidup gerakan-gerakan yang dilakukan oleh Ida berdampingan dengan yang sakral, serta Pedanda, peserta Otonan, serta Srati Mangku bagaimana hubungan antara agama dengan selama prosesi ritual Otonan berlangsung. kebudayaan.Dalam setiap prosesi ini Seluruh gestural ini memiliki makna memiliki doa yang berbeda-beda, sesuai tersendiri yang ingin disampaikan, dengan fungsinya. Prosesi Mebyakaonan namuntidak banyak orang yang bisa terdiri dari empat scene. Berdasarkan analisis memahaminya. Suatu penyampaian pesan makna-makna yang telah dijabarkan, dalam kegiatan komunikasi akan lebih mudah dilakukan jika terjadi komunikasi verbal dan nonverbal, di mana komunikasi nonverbal mendukung dan memperkuat makna yang ada dalam komunikasi verbal. Dalam ritual Otonan ini, makna-makna yang disampaikan di dalamnya akan lebih mudah dipahami dengan adanya tanda visual, tanda verbal, serta tanda audio yang ada di dalamnya. Ketiga tanda yang ada dalam ritual Otonan ini memiliki makna-makna tersendiri yang belum diketahui oleh banyak orang. Ketiga tanda tersebut kemudian dapat diaplikasikan dengan menggunakan semiotika untuk mengungkap makna-makna yang terkandung di dalamnya. Dalam hal ini, peneliti menggunakan semiotika Roland Barthes untuk mengungkap makna-makna yang terkandung dalam ketiga tanda tersebut, di mana pencarian makna ini dilakukan dengan empat tahap, yaitu denotatif, konotatif, mitos dan ideologi.

Ritual Otonan terdiri dari dua prosesi yaitu Mebyakaonan dan Meprayascitta. Penelitian ini membedah prosesi Mebyakaonan, karena dalam prosesi ini lebih terdapat suatu konsep yang disebut dengan hierofani. Hierofani dapat diartikan sebagai suatu perwujudan atau penampakan diri dari yang sakral. Dalam setiap ritual, mitos, bentuk-bentuk suci, simbol-simbol, binatang, tumbuh-tumbuhan, tempat-tempat suci, orang-orang suci, dll, semuanya itu dipandang sebagai hierofani. Bhuta kala adalah hierofani. Ida Pedanda sebagai pemimpin ritual Otonan adalah hierofani. Tri Murti adalah hierofani. Sapi sebagai kendaraan dewa Siwa adalah hierofani. Seluruh mitos yang ada pada ritual Otonan adalah hierofani. Serangkaian tanda visual, verbal, dan audio dalam ritual Otonan adalah hierofani. Ritual Otonan adalah hierofani. Selain itu, ritual Otonan juga merupakan ungkapan religius kolektif. Ekspresi iman yang dilakukan bersama-sama tidak dapat dipisahkan dari konteks kebudayaan bangsa tertentu. Ritual Otonan yang merupakan ritual keagamaan Hindu yang disusun berdasarkan pola kebudayaan tertentu.

Ideologi tidak berbicara mengenai kebenaran, tidak berbicara mengenai kenyataan empirik, akan tetapi ideologi 
berbicara mengenai kemanfaatan, kepentingan, kemauan, dan pamrih. Dari hasil analisis tanda visual, verbal, serta audio dengan menggunakan pendekatan semiotika Roland Barthes, di mana dari ketiga tanda tersebut menghasilkan makna denotatif, konotatif, serta mitos, terdapat ideologi yang terkandung dalam ritual Otonan ini, yaitu religiusitas. Religiusitas berasal dari kata 'religi', yang lebih popular ketika membahas mengenai tradisi-tradisi dan keyakinan dalam kebudayaan manusia. Religi berasal dari bahasa latin, yang sering dieja religio. Cicero, seorang penulis Romawi, menyatakan bahwa 'religi' (religion) berasal dari kata 'leg' yang berarti 'mengambil' atau 'menjemput', 'mengumpulkan, 'menghitung', atau 'memperhatikan'. Sementara, Sevius berpendapat bahwa 'religi' berasal dari kata 'lig' yang berarti mengikat. Maka, religi atau religion berarti suatu perhubungan antara manusia dengan zat yang di atas manusia (supra manusia). Dalam hubungannya dengan antropologi, istilah religi berkaitan dengan suatu sistem keyakinan masyarakat yang bersahaja sebagai produk budayanya (Ghazali, 2011:5).

Sartono Kartodirdjo (dalam Ghazali, 2011:6) menyebutkan lima unsur ke dalam dimensi-dimensi religiusitas sebagai berikut:

a. Dimensi pengalaman, mencakup semua perasaan persepsi dan sensasi yang dialami waktu berkomunikasi dengan realitas supernatural;

b. Dimensi ideologis, mencakup serangkaian kepercayaan;

c. Dimensi ritual, mencakup semua aktivitas seperti upacara, berdoa, dan partisipasi dalam berbagai kewajiban agama;

d. Dimensi intelektual ideal, berhubungan dengan pengetahuan tentang ajaran agama;

e. Dimensi 'konsekuential', mencakup semua efek dari kepercayaan, praktik, pengetahuan dari orang yang menjalankan agama, dengan perkataan lain, semua perbuatan dan sikap sebagai konsekuensi beragama.

Ritual Otonan merupakan salah satu bentuk ritual keagamaan Hindu, khususnya untuk memenuhi Manusa Yadnya. Seluruh tanda yang ada yang tanda visual, verbal, dan audio memaknai fungsi-fungsi religius. Misalnya pada kegiatan metirtha. Kegiatan metirtha ini bertujuan untuk memohon kepada Tuhan untuk membersihkan diri secra lahir dan batin, dengan menggunakan air tirtha sebagai medianya. Pada tanda audio yaitu bunyi lonceng yang terdengar selama Ida Pedanda mengucapkan doa, dengan maksud untuk menjernihkan pikiran, membantu berkonsentrasi, dan mengiringi doa-doa yang diucapkan. Pada tanda audio 
yaitu bunyi lonceng yang terdengar selama Ida Pedanda mengucapkan doa, dengan maksud untuk menjernihkan pikiran, membantu berkonsentrasi, dan mengiringi doa-doa yang diucapkan.

Ideologi lain adalah bahwa agama sebagai sistem budaya. Dalam kehidupan sehari-hari, agama memberikan kontribusi yang besar terhadap nilai-nilai budaya yang berlaku pada masyarakat setempat. Contohnya pada ritual Otonan adalah penggunaan saput oleh peserta (laki-laki) selama ritual Otonan. Umat Hindu selain Hindu Bali belum tentu menggunakan pakaian adat yang sama persis dalam pelaksanaan ritual keagamaannya, contohnya adalah penggunaan saput yang digunakan di tubuh bagian bawah laki-laki, yang digunakan setelah kamen. Umat Hindu yang bukan berasal dari Bali belum tentu menggunakan saput dalam ritual keagamaannya, karena mereka memiliki sarananya sendiri. Contohnya adalah umat Hindu di Jawa (bukan asli Bali), di mana kaum laki-laki biasanya hanya menggunakan kamen ataupun sarung. Hal ini menunjukkan bahwa agama tidak akan bisa terlepas dari kebudayaan setempat.

\section{SIMPULAN}

Secara sederhana, makna denotatif merupakan makna yang sebenarnya dari sebuah kata. Makna denotatif adalah makna yang biasanya ada pada kamus. Dalam hal ini, doa-doa yang ada pada ritual Otonan secara denotasi adalah doa-doa yang dipanjatkan selama ritual Otonan, khususnya pada prosesi Mebyakaonan. Secara singkat, doa untuk prosesi Mebyakaonan berisi tentang haturan-haturan yang disiapkan kepada para bhutakala. Selanjutnya adalah tanda visual yang fokus pada gestur, warna, dan pakaian yang dapat diamati dari 4 scene yang ada pada prosesi Mebyakaonan dalam ritual Otonan. Masing-masing scene ini terdiri dari tanda visual yang berbeda-beda, walaupun ada beberapa gerakan yang sama. Contohnya adalah kegiatan metirtha yang dilakukan dengan cara mengetiskan air tirtha pada peserta Otonan. Ada pula tanda audio yang didapatkan dalam ritual Otonan ini, yaitu bunyi lonceng atau bajra/genta. Lonceng ini akan digerakkan oleh Ida Pedanda hingga menghasilkan bunyi, dan dilakukan selama beliau mengucapkan doa.

Setelah denotatif, peneliti menganalisis pemaknaan secara lebih dalam lagi hingga ke tahap konotatif. Pada doa untuk prosesi Mebyakaonan, makna konotatifnya adalah bahwa selama proses Otonan berlangsung, Ida Pedanda meminta kepada para bhutakala untuk tidak mengganggu jalannya ritual Otonan, namun sebisa mungkin dapat membantu. Hal ini dilakukan dengan cara memberikan sesajen untuk mereka. Pada tanda visual, peneliti menemukan bahwa dalam 4 scene tersebut memiliki makna konotatif yang erat dengan ajaran-ajaran 
dalam agama Hindu, walaupun ada beberapa yang makna konotatifnya erat dengan kebudayan Bali. Seperti kegiatan metirtha yang memiliki makna konotatif membersihkan diri manusia secara lahir dan batin, kemudian ada penggunaan pakaian yang berwarna putih yang memiliki makna konotatif yang suci dan bersih. Ada pula makna konotatif yang erat dengan kebudayaan Bali, contohnya adalah penggunaan pakaian adat Bali dalam ritual otonan, yaitu penggunaan saput pada peserta Otonan (pria), dan penggunaan pakaian adat ke Pura bagi para Srati Mangku (pembantu mangku). Adapun pada tanda audio di mana lonceng dibunyikan selama Ida Pedanda memanjatkan doa memiliki makna konotasi bahwa bunyi lonceng tersebut akan mengiringi doa-doa yang dipanjatkan, serta dapat menghilangkan suara-suara yang mengganggu pikiran dan dapat membantu pikiran untuk berkonsentrasi dalam mencapai pemujaan.

Berdasarkan analisis makna-makna yang telah dijabarkan, terdapat suatu konsep yang disebut dengan hierofani. Hierofani dapat diartikan sebagai suatu perwujudan atau penampakan diri dari yang sakral. Selain itu, ritual Otonan juga merupakan ungkapan religius kolektif. Ekspresi iman yang dilakukan bersama-sama tidak dapat dipisahkan dari konteks kebudayaan bangsa tertentu (Hendropuspito, 1993:112). Dari hasil analisis tanda visual, verbal, serta audio terdapat ideologi yang terkandung dalam ritual Otonan ini, yaitu religiusitas. Sartono Kartodirdjo (dalam Ghazali, 2011:6) menyebutkan lima unsur ke dalam dimensidimensi religiusitas, yaitu dimensi pengalaman, dimensi ideologis, dimensi spiritual, dimensi intelektual ideal, dan dimensi 'konsekuential'. Ideologi lain adalah bahwa agama sebagai sistem budaya. Dalam kehidupan sehari-hari, agama memberikan kontribusi yang besar terhadap nilai-nilai budaya yang berlaku pada masyarakat setempat.

\section{DAFTAR PUSTAKA}

Bungin, Burhan. (2013). Penelitian Kualitatif. Jakarta: Prenada Media Group.

Cooper, J.C. (2013). An Illustrated Encyclopaedia of Traditional Symbols. London: Thames \& Hudson.

Danesi, Marcel. (2010). Pesan, Tanda, dan Makna. Yogyakarta: Jalasutra.

Ghazali, Adeng Muchtar. (2011). Antropologi Agama: Upaya Memahami Keragaman Kepercayaan, Keyakinan, dan Agama. Bandung: Alfabeta.

Hendropuspito. (1993). Sosiologi Agama. Yogyakarta: Kanisius

Kaplan, David. (2012). Teori Budaya. Yogyakarta: Pustaka Pelajar Offset.

Koentjaraningrat. (2011). Pengantar Ilmu Antropologi. Jakarta: Rineka Cipta.

Kriyantono, Rakhmat. (2006). Teknik Praktis Riset Komunikasi. Jakarta: Prenada Media Group.

Liliweri, Alo. (2002). Makna Budaya dalam Komunikasi Antar Budaya. Yogyakarta: LKiS.

Piliang, Yasraf Amir. (2012). Semiotika dan Hipersemiotika: Kode, Gaya \& Matinya Makna. Bandung: Matahari. 
Pudharta, Ida Bagus Putra. (2000). Puja Pangastawa. Gianyar.

Pujileksono, Sugeng. (2015). Metode Penelitian Komunikasi: Kualitatif. Malang: Kelompok Intrans Publishing.

Rakhmat, Jalaludin. (2007). Psikologi Komunikasi. Bandung: PT Remaja Rosdakarya.

Sinar, Tengku Silvana. (2012). Teori \& Analisis Wacana: Pendekatan Linguistik Sistemik-Fungsional. Sumatera Utara: CV. MITRA Medan.

Sobur, Alex. (2013). Semiotika Komunikasi. Bandung: PT Remaja Rosdakarya.

Sugiyono. (2012). Metode Penelitian Kuantitatif dan Kualitatif. Bandung: Alfabeta.

Kamus Peribahasa. [Online] Available at: https://rebanas.com/kamusperibahasa/proverbs?kata=beras [Accessed 20 Desember 2016].

Lunturnya Tradisi Budaya Otonan. [Online] Available at: http://catatanbiodatadiri.blogspot.co.id/ 2013/12/lunturnya-tradisi-budayaotonan.html [Accessed 12 September 2016].

Novianti, Evi. Desember 2014. Pola Komunikasi Pasangan Antaretnik SundaMinang di Bandung. Jurnal Kajian Komunikasi Universitas Padjajaran, Volue 2, No. 2 [Online] Available at: http://jurnal.unpad.ac.id/jkk/article/vie $w / 7383 / 3386$ [Accessed 21 December 2016]. 